\title{
Sustainability, nature, and education: a phenomenological exploration
}

Summary: This paper begins with a brief evaluation of the notion of sustainable development as an influential orientating idea for environmental education. It is argued that the strong anthropocentrism that can be detected in dominant versions of this idea needs to be complemented by a deeper non-anthropocentric understanding of sustainability. It is believed that this latter has radical implications for education because it reveals the way in which human consciousness is itself inherently environmental. It is argued that nature is a key reality that engages this environmental consciousness and that a phenomenology of nature discloses features of our direct experience of the natural world that are seminal to understanding environmental education, and that have important implications for education as a whole. In particular, the problem of the influence of scientism is raised.

Key words: sustainability, nature, environmental education, education for sustainable development.

\section{Sustainable development as an orientating idea for environmental education}

Over the past three decades the idea of sustainable development has become a central policy response to the growing recognition of the environmental degradation that now confronts humankind. Its most influential definition was provided by the Report of the Brundtland Commission Our Com- mon Future in 1987 where sustainable development was defined as: 'a development that meets the needs of the present generation without jeopardising the ability of future generations to meet their needs' ( $\mathrm{p}$. 54). This definition found widespread acceptance and was consolidated as an educational concern at the Earth Summit Conference held in Rio de Janeiro in 1992. Attended by delegates from over 170 countries, its centre-piece agreement was Agenda 21 (UNCED, 1992) that included the proposal to intro-

1 mrb25@cam.ac.uk

Copyright $\odot 2016$ by the authors, licensee Teacher Education Faculty University of Belgrade, SERBIA.

This is an open access article distributed under the terms of the Creative Commons Attribution License (CC BY 4.0) (https://creativecommons.org/licenses/by/4.0/), which permits unrestricted use, distribution, and reproduction in any medium, provided the original paper is accurately cited. 
duce 'sustainable development' into the educational programmes of signatory nations. By this means it achieved a place (at least notionally) in the core curriculum of many nations, giving rise to the notion of education for sustainable development. The significance of this idea was lent further impetus by the decision of the UN General Assembly in December 2002 to launch the Decade of Education for Sustainable Development 2005-14.

However, while enjoying extensive political currency, this formulation of sustainable development has been subjected to a fair amount of philosophical scrutiny and criticism (see, for example, Jickling, 1992; Bonnett, 1999). While recognising that the notion has the virtue of incorporating the need for economic development where, for example, it is necessary in order to combat widespread poverty and disease, the criticisms have been wideranging. They include fundamental ambiguities of interpretation (for example, the criteria for identifying and evaluating 'needs'), unexamined ethical assumptions (for example, about the rights and duties of humankind towards the rest of nature), and extensive epistemological problems arising from the inadequacy of our current understanding of the long term consequences of specific policies or actions for natural systems, given the complexity and geographical and temporal scales of the latter. I will not rehearse all the arguments in detail here, but will focus on one argument that I take to reveal an important understanding of sustainability that has fundamental implications for education.

\section{The focus on human needs}

A striking feature of currently dominant versions of sustainable development, illustrated by the Brundtland definition given above, is both their exclusive focus on human needs and an economistic interpretation of these needs. I will argue that while in the present social/political climate these modulations are entirely understandable, from the point of view of developing an understanding of sustainability that will enable us authentically to comprehend our environmental situation they are fundamentally flawed. The central problem is that such modulations represent an unreflective expression of a burgeoning metaphysical stance that lies at the heart of our current environmental predicament: the holding sway of a metaphysics of mastery. By this latter, I refer to a way of revealing the world - and in this sense, the creation of a reality - in which everything is regarded as a resource. Here, ultimately, the being of everything that we encounter is to be understood in terms of how it serves or frustrates the human will. Nothing is simply accepted as it is, and for what it is, but rather for how it might be brought into service. At the cultural level this stance is evidenced by the strength and character of the consumerist economic motives that dominate Western style society and that continue to countenance widespread exploitation and despoliation of the natural world and encourage the commodification of all as natural or human 'capital'. Here 'progress' consists in stimulating and meeting ever-rising material expectations and an insatiable utilization of nature, success being viewed in terms of narrowly focussed ideas of growth and efficiency that habitually externalise harmful collateral effects until their impact is so great that they can no longer be ignored. Our growing awareness of anthropogenic global warming is one example of this.

Although this cultural motive of seeking mastery has long been on its way (for example, there is evidence to suggest that in the Hellenistic period there was optimism over the ingenuity of man and his technology to shape nature (Glacken, 1967, pp. 117-120)), in the past it has often been held in check by other motives and factors such as religious precept and regard for the 'sacred', respect for what were regarded as immutable natural processes, and limited human capacity such as know-how and physical power. However, with the demise of many traditional sources of authority, the rise of secularism and the growth of modern technology (that also can be con- 
sidered as an expression of the metaphysics of mastery) increasingly mastery seems ever more plausible and the desire for it achieves free rein. Discontent with - even disdain for - what is given becomes à la mode. With ever increasing determination, humankind 'needs' to order, control, manipulate and exploit every aspect of its environment. Or to create alternative - for example, virtual or digitally augmented - environments/realities that are constructed to meet its ever-expanding requirements and palette of appetites and satisfactions.

This proclivity is reflected in the way that the development of a society fundamentally becomes interpreted in material economic terms that are captured through measures of productivity and gross domestic product, and the components and infrastructures that enhance these. Here, a broader conception of cultural development that reflects the flourishing of the arts and humanities and the quality of ethical and political life drops out of view. Arguably, a society that operates economically at subsistence level, nonetheless, could embody more authentic and higher levels of cultural development in this sense than one displaying high levels of economic growth. As C. A. Bowers has noted, the fact that some high status ways of thinking in the West characterize subsistence cultures as 'undeveloped' or 'backward' overlooks the fact that they are '.. contemporary in every sense except for the modern technology they have avoided embracing' (Bowers, 2001, p.11).

The thinking behind this remark is not easily to be dismissed, for not only are these cultures contemporary (if now highly endangered), but they have for the most part succeeded in living in their environments over millennia without systematically destroying them. It has been suggested by David Abram that, indeed, they express a seminal kind of truth that has largely fallen out of focus in modern scientifically orientated Western culture: the idea of living in truth as opposed to the analytic gathering of objective truths. Here attention is upon the qual- ity of our living relationship with the thing known: the way that we are towards it rather than objective knowledge in which the subjectivity of the knower is separated from the known. Reflecting on indigenous cultures, Abram puts forward the thought that:

Ecologically considered, it is not primarily our verbal statements that are "true" or "false", but rather the kind of relations that we sustain with the rest of nature. A human community that lives in a mutually beneficial relation with the surrounding earth is a community, we might say, that lives in truth. The ways of speaking common to that community - the claims and beliefs that enable such reciprocity to perpetuate itself - are, in this important sense, true.... A civilization that relentlessly destroys the living land it inhabits is not well acquainted with truth, regardless of how many supposed facts it has amassed regarding the calculable properties of its world. (Abram, 1996, p. 264)

The central problem here is that the truths that such a civilization gathers are not understood holistically. This is true in two senses. First, its truths are often motivated by, and when not this rapidly assimilated to, very partial sets of purposes such as intellectual mastery, economic competiveness, and a variety of other egocentric satisfactions. Second, they lack an ethical grounding in a love of the world, particularly the natural world, in which humankind is embedded. In the process of acquiring truth, love of what reveals and a sense of gratitude for what is vouchsafed are occluded by overweening discontent and ambition. With regard to the natural world, little is received any longer as a gift. Rather, it is perceived as the result of human demand and manipulation. As Heidegger (1977) observed in his account of the essence modern technology, our relationship to the earth has become a challenging such that it now reveals itself as, say, a source of minerals, or as a landscape on call for the tourist industry. The field that the peasant once cultivated appears differently to when cultivating meant to take care of and to maintain. Here, in the sowing of the grain the work of the peasant was to place the seed in the keeping of 
the forces of growth and to watch over its increase. Today, agriculture has become the mechanized food industry that 'sets upon' nature, challenging it to produce maximum yield at minimum expense (Heidegger 1977, p. 15).

What we have here is a pervasive disdain for given reality and the authority of nature. Hannah Arendt (1998) observed that in late-modern times man (sic) seems

"possessed by a rebellion against human existence
as it has been given, a free gift from nowhere (sec-
ularly speaking) which he wishes to exchange, as
it were, for something he has made himself." (pp.
2-3)

In the academic field in which postmodernism and poststructuralism as broad cultural/philosophical movements have gained the ascendence, Ursula Heise claims that:

... the basic goal of work in cultural studies for the last twenty years has been to analyze and, in most cases, to dismantle appeals to "the natural" or the "biological" by showing their groundedness in cultural practices rather than facts of nature. The thrust of this work, therefore, invariably leads to skepticism about the possibility of returning to nature as such, or of the possibility of places defined in terms of their natural characteristics that humans should relate to. (Heise, 2008, p. 46).

In sum, increasingly, (Western) humankind has extracted itself from immersion in the given. Rationalistic modes of perception have separated mind from body and humanity from nature, culminating in a view that the latter is essentially a human construction and that knowledge itself is the result of human ingenuity rather than receptivity to otherness - something beyond human authorship. The movement described above in cultural studies has a parallel in the physical sciences in the phenomenon of the objectification and mathematization of nature.

While this abstraction from the immediately given and an accompanying instrumental stance has brought material benefits, arguably it also represents a kind of depletion of consciousness that hinders our ability to respond adequately to our current environmental situation in all its facets. It suffers from the illusion that what its abstractions can comprehend and what its instrumental frame presents to it is all that matters. By contrast, I will argue that human consciousness is inherently environmental in that it constantly relates to a transcendent world beyond its authorship and that fundamentally orientates it and populates its experience. While instrumentality is, indeed, a necessary way of engaging with and revealing the world, only through wholehearted participation in a more open relationship can consciousness gain knowledge of its environment sufficient to revealing appropriate responses to the deep seated problems that now confront it.

\section{Environmental consciousness}

Central to the idea of human consciousness is the notion of truth - the latter here understood in the Heideggerian sense of the showing up of things themselves. In other work (Bonnett 2016), and drawing on the early work of Edmund Husserl, I have developed the claim that consciousness is nothing without its things - to which, constantly, it is directed and for the sake of which, it allows space. In this sense it is inherently environmental.

The argument goes as follows. Phenomenologically, we find that, at some level, consciousness is always directed upon something, whether it be a physical phenomenon, an idea, or a feeling. In this sense it is intentional, or 'minded'. Husserl (2001) makes the important point that the things to which consciousness is directed - its intentional objects are not simply possessed within itself, but are transcendent. For example, when we desire something such as a new coat, we do not desire something that is already present within consciousness, say as an image or an idea, but an actual coat whose existence lies beyond any individual consciousness. Similarly, 
when we think of an abstract idea such as freedom, this is something whose existence - intelligibility lies in it being a shared notion intimately connected with a world that is not exclusively contained within an individual consciousness. Indeed, as Martin Heidegger (1972) makes clear, these transcendent objects towards which consciousness is directed are experienced as always already existing in a world that they share with us. Such 'worldliness' is fundamental to their intelligibility. In this seminal sense, human consciousness is ecstatic: it exists in a constant (and complex) motion of standing out towards things beyond itself in the world. It is therefore inherently worldly - and hence, we can say, environmental.

Relevant to this understanding of consciousness, Hannah Arendt opens her influential book The Life of the Mind, by exploring the claim that what all things in the world have in common is that they appear and hence are meant to be perceived:

Being and Appearing coincide. Dead matter, natural and artificial, changing and unchanging, depends in its being, that is in its appearingness, on the presence of living creatures. Nothing and nobody exists in this world whose very being does not presuppose a spectator. (Arendt, 1978, p. 19)

She refers this back to Edmund Husserl's development of the intentionality thesis of consciousness, claiming that:

Husserl's basic and greatest discovery . . is the fact that no subjective act is ever without an object . . objectivity is built into the very subjectivity of consciousness by virtue of intentionality. Conversely and with the same justness, one may speak of the intentionality of appearances and their built-in subjectivity. All objects because they appear indicate a subject, and, just as every subjective act has its intentional object, so every appearing object has its intentional subject. (p. 46)

Now this portrayal of the fundamental nature of human consciousness leads to an interesting idea: there is an important sense in which it is ineluctably involved in sustainability. It becomes the place where things appear. It lets them be. In doing this it sustains them as the things that they are. Also, very importantly, it is sustained by them. The life of consciousness is sustained by the things that appear to it: Its being consists in its participation in its relationship to the being of the things that appear to it. Things exist in their meaning to be perceived, and consciousness exists in its meaning to perceive them.

It seems to me that such ecstasis (intentionality) is, indeed, a central characteristic of human consciousness. In the light of this I will now argue that it is through an engagement with nature that its ecstatic character is most fully realised, and that therefore in this sense the phenomenological reality of nature is a key reality for our authentic being.

\section{Nature as a key reality}

I would like to begin by stating what I take to be an uncontroversial claim concerning the significance of nature for human being: historically, and indeed prehistorically, engagement with the natural world has been a primordial experience for humankind. From the beginning we have been both embedded in nature and have needed to interact with it for our survival. In such a situation it could hardly fail to have shaped the evolution of our physiology, including that of our senses, and to have fundamentally conditioned our understanding of ourselves and our place in the world. We arose as embodied beings coping in a world in which many of the most significant givens emanated from nature. Of course, this is not the whole story - we are also social and cultural beings, and these phenomena, too, have shaped us - but for millennia, our encounters with nature have been highly influential conditioners of human being.

In relation to this claim, and from a phenomenological perspective, an important caveat needs to be entered: life in our late-modern period hardly foregrounds any such view. By way of rejoinder to this, it will be argued that nonetheless there is an 
important sense in which nature continues as a primordial reality for us, and constitutes an important environment for the realization of our authentic being. I will develop each of these points in turn.

\section{Nature through the lens of modernist humanism}

The development of the European Enlightenment brought to prominence a constellation of ideas that had a profound effect on our relationship with nature. Since they help to illustrate and to amplify my previous allusions to the influence of abstract reason and instrumentalism in experience, I rehearse some key elements below (they are heavily interwoven and separated out only for the purpose of exegesis).

First, there was the elevation of a version of human reason as the means to understanding the world that was linked to reinforcing aspirations and belief in the possibilities of subjugating nature to the service of human purposes. While, as noted in my earlier discussion of the metaphysics of mastery, motives of this general kind stem back to antiquity, it was during the European Enlightenment that they became distilled and encoded in a particularly potent form that projected nature as essentially an inexhaustible resource. This portrayal of nature both conditioned the spirit in which it was studied - for example, Francis Bacon's recommendation, at the inception of modern science, that science wholeheartedly adopt utilitarian motives - and was conducive to the aspiration to make nature 'on-hand' wherever possible. Martin Heidegger (1977) has described this latter as seeking to convert nature into a 'standing reserve' that can be endlessly switched around in the service of human consumption. Here is revealed the final goal of anthropocentric mastery.

Second - and intimately bound up with the preceding point - there was the supposition that nature is to be adequately accounted in terms of humanly constructed categories and theories. In our exploration of nature, our stance should be that of interrogator who, according to Bacon, needs to 'torture nature's secrets from her' (cited in Capra, 1982, pp. 40-41). Another luminary of the Enlightenment, Immanuel Kant, put it this way:

Reason must approach nature not 'in the character of a pupil who listens to everything that the teacher chooses to say, but of an appointed judge who compels the witness to answer questions which he has himself formulated ... it must adopt as its guide ... that which it has itself put into nature. It is thus that the study of nature has entered on the secure path of a science, after having for so many centuries been nothing but a process of merely random groping.' (Kant, 1970, p. 20)

Clearly, this view would heavily discount the kind of knowledge gained by an intimate living with nature - such as that celebrated by indigenous cultures - and the abstraction and idealisation set in train is highly commensurable with supposing that in essence nature is (merely) a human construction. In the hands of postmodern/poststructuralist accounts it becomes perceived as a product of our categories, theories, narratives, and texts. MerleauPonty (1962, p. 300) notes, how, on this trajectory, reality becomes not something given in experience - 'a crucial appearance underlying the rest' - but rather a superordinate 'framework of relations with which all appearances tally' This is highly congenial to supposing that the most fundamental structures of nature can be articulated in mathematical terms, and this is precisely the project that the thinking of Galileo set in train. Today, it seems relatively unremarkable to suppose, as with the physical sciences, that the basic workings of the universe can be captured and explained by mathematical equations and that particular things and phenomena receive their most fundamental articulations by being assimilated to the structures that result.

Third, nature is understood as a realm set apart from the human - its fundamental constitution being conceived as purely physical matter/energy operating according to blind universal laws. Here we are presented with a mechanical causal or proba- 
bilistic system entirely innocent of internal purpose and meaning, and therefore incapable, in itself, of expressing normativity or possessing inherent intrinsic value. This positing of nature as purely physical is particularly overt in the thinking of Descartes and itself expresses the deeper presumption that the structure of reality is to be supplied by the imposition of impersonal rational cognitive categories and ordering previously described rather than, say, through an affective sensibility that is open to aesthetic qualities, felt value and worth, emanating from a sense of the individuality and uniqueness of things in their sheer standing there.

Hence, rather than providing a privileged access to the reality of nature, scientific narratives have the effect of effacing important aspects and, indeed, of subverting its authentic significance for humankind. Perhaps this is acceptable within the discipline of science itself when its limitations are acknowledged and accepted as a price worth paying for achieving a particular kind of objectivity. ${ }^{2}$ But when its presumptions, methodologies and pronouncements become generalised beyond the discipline and assume the countenance of arbiter of thinking and understanding more broadly, great damage is done. It is this phenomenon that I refer to as scientism. Unfortunately, this generalizing of scientific presumptions is pervasive. It sets the tone for many activities that lie beyond its scope, including that of education where it inspires attempts to pre-specify the curriculum and to measure success in terms of publicly observable outcomes - often expressed as mathematical scores - that can be objectively compared across a wide range of situations.

In what follows I will attempt to elucidate some of the ways in which this constellation of ideas plays into both a defective understanding of ourselves and a defective basis for decision-making on environmental matters.

2 For an alternative understanding of science that portrays it as less aggressive and instrumental, see Joldersama (2009). Unfortunately, in many contexts it is still an essentially Baconian conception that prevails.

\section{A phenomenological approach to nature}

Contrary to the view of nature that emerges through the prism of modernist humanism, it will be argued that a phenomenological approach reveals nature to be far from an essentially mechanical realm that can be adequately accounted for by the physical sciences and the application of mathematics. Nor, indeed, can its essential character be revealed by the ecological sciences that have been one of the main instigators of current environmental concern through exploring the now extensive impact of human behaviour on an environment of nested systems whose fragility is becoming ever more apparent. While, undoubtedly, such studies have important contributions to make, because of their limited understandings of nature it is essential that these limitations are made explicit and that their narratives are referred back to a direct experience of nature that simply cannot be contained or communicated by the abstract categories and physicalisation of natural phenomena promoted by modernist reason/science.

Focussing, therefore, on this issue, the key feature of our experience of nature qua nature - that is to say the experience that determines our concept of nature - is its independence of our authorship and will. Contrary to previously mentioned views that encourage us to understand nature as a social construction, phenomenologically things in nature befall us in their individuality and particularity as quintessentially non-artefactual. They are always there already, without any reference to what we might intend. In this sense we experience them essentially as self-arising (Bonnett, 2004).

To be sure, this is not to say that we do not affect nature in all sorts of ways. Rather it is to say that in all our interactions with nature there remains something that is 'other', always beyond us and experienced as occurring from out of itself. This is fully compatible with the idea that our linguistic articulations of nature occur through concepts that have 
been socially produced. Perhaps, on a sea shore walk my attention is suddenly caught by the glistening of foam capped waves of the incoming tide stirred by a freshening breeze. Clearly, this experience is articulated through the relevant socially produced concepts, but that the waves moved in this way and were caught by sunlight at this moment is perfectly independent of these concepts. Furthermore, allowing that the concepts through which we articulate our experiences of nature are socially produced is not to say that we are 'sole authors' of these concepts. They arise through our intercourse with the otherness of nature and are not simply our product in the sense that we can know what they articulate from the inside and can reconstruct it at will. Non-human elements are in play.

Having claimed this essential self-arising character for nature, it also needs to be acknowledged that this is not always prominent in our myriad encounters with nature. On occasion it may be heavily veiled or subverted. For example, under the influence of scientism and the metaphysics of mastery previously discussed, increasingly we come to see things in nature in purely instrumental or economic terms, paying little or no attention to their particularity and otherness. Yet, insofar as we do still construe something as a part of nature, the idea of it as self-arising remains implicit. Indeed, this understanding of nature as an independent reality is deeply embedded in our form of sensibility as a whole. Historically, our senses and understanding evolved in response to otherness, creating an intelligible environment for us to inhabit. The presence of self-arising nature has been a powerful, and the most pervasive, element of this independent reality in which we are embedded and whose existence is central to the intelligibility of ideas and motives that are key to human consciousness such as perception, description, and truth. The logic of such terms requires a transcendent reality to be perceived or described. Without such a reality to relate to, human consciousness would implode (as the intentionality thesis makes clear).
Hence, the essential autonomy and otherness of nature arises in the context of a complex inter play with human purposes. Our contact with an intelligible world is modulated by the purposes and practices that we pursue. But, also, aspects of that world can announce themselves 'uninvited. They can command our attention and initiate our thinking- as when, say, we are struck by the magnificence of the night sky or the power of a storm. Furthermore, our artefacts are frequently both shaped by our awareness of aspects of nature with which we have to contend, such as the weather, and can reveal facets of that nature such as the way that a ship's bow throws back the water, displaying its fluidity. Our overarching form of sensibility evolves and is extended through this intimate interplay in which occurs a reciprocal conditioning of human purposes and artefacts with the appearing of nature in its otherness. It follows, therefore, that, as always appearing within this form of sensibility, the nature that we experience has a human reference, but ultimately it is not simply a human construct. Phenomenologically, the living presence of natural things is something we behold rather than construct, and we construe them as having their own 'lives' and interactions, regardless of whether we witness them or happen to think about them. They have countenances and profiles, pasts and futures, that lie always beyond us and in this sense they are inherently mysterious, as when a flying insect passes us on the warm dusk air.

This reference to the experience of the living presence of natural things prompts mention of another central feature of self-arising nature. There is an important sense in which things in nature exist always in relationship: not now as the defined objects or constructs of scientific ecology, such as species, populations, and ecosystems, but in their very occurring - in their being. Suppose, on a woodland walk, we encounter a beech tree in spring. The manner in which this tree occurs for us - its living presence - arises through continuous myriad interplays, for example: between the tree and neighbouring vegetation as their branches intermingle and cast pass- 
ing shadows, the play of sunlight bringing its leaves to shimmer, the rustle of birds flitting through its canopy, the aggregations of moss and lichen on its limbs, the enveloping odours of growth and decay, the gathering of midges beneath its branches as dusk falls, the felt presence of what might be hidden, or is yet to appear.

Here the character of the living presence of each thing - its occurring as the thing that it is in our immediate multisensory experience of it - arises through the intimate interrelationships in which it participates. These relationships are therefore ontological and constitute a place-making. The living presence of each individual is sustained through its participation in a creative interplay with its neighbours that upholds the special ambience of the place in which they are encountered. This place is both sustained by them and is sustaining of them. If the beech tree were to be felled, all would be irrevocably changed. Not just the living presence of the tree, but that of everything else will have passed away. ${ }^{3}$

Furthermore - and very importantly - entering such a natural place and participating in the occurring of such place-making, our senses now resonating with what befalls us, our own embodied being is enlivened and refreshed. For a while our environmental consciousness is fulfilled. This is a central aspect of the importance of self-arising nature. When it occurs we experience an ecstasis that can be inspirational. The multi-sensory and super-sensor $y^{4}$ invitations to engage with possibilities of oth-

3 Of course, they continue to exist as bio-physical objects. The point is intended to alert us to another, perhaps more important, sense in which also they no longer exist as before: the former manner of their being present has been destroyed. This active 'presencing' is what constitutes their being in our direct experience of them, and it is the fullness of this experience that furnishes us with a portal to things themselves in nature. Ultimately, all objectification has to be referred back to this originating experience if its nature, and the true nature of the thing objectified, are to be understood.

4 I use this term to refer to the sensing of non-physical properties such as normativity, ambience, and the latent reality of what is currently withdrawn, or is not yet. erness and mystery that it offers can break the hold of everyday scientistic preconceptions and instrumental knowingness that keep us attuned to the deadness of the possessively known rather than the vibrant call of the unknown, the withdrawn (Bonnett, 1995). Things in nature communicate aspects of their being that always lie beyond us, are yet to be revealed, no matter how developed our scientific understanding becomes. Indeed, when their living presence becomes codified in some database pro forma of objective defining properties its essence simply evaporates. The spontaneous appearing (and disappearing) of their immediate reality becomes ossified, transmuted into fixed abstractions taken to define them. And our sense of the elemental powers that pervade their being - such as those of birth and death, lightening and darkening, sound and silence, motion and stillness, and so forth - is stifled (Bonnett, 2015).

Finally, there is another important consideration: the possibility of our attunement to the inherent integrity and normativity of things in nature. Although they are profoundly other, when we are attuned to them, things in nature communicate something of their own integrity such that we can have a sense of what counts as their well-being. In this sense they are normative and possess intrinsic value. A stark and negative example of our awareness of this can be evoked if perhaps, we witness the sickly movement of waves covered by an oil slick and the devastation wreaked on the fauna and flora of the fore shore. Conversely, on entering the woodland dell in spring we might be struck by a sense of rightness that emanates from the myriad interplays, harmonies and contrasts, subtle adaptions and accommodations that come to our attention. Here, things presence in such a way that how they are communicates that this is how they ought to be (Bonnett, 2012; see, also, Skulason, 2015). This communication is not something that can be captured in a set of abstract moral principles, nor can it provide specific moral prescriptions. Rather it is an emplaced pre-moral sensing of what belongs and what 
is fitting, respect for which is a pre-condition of a properly informed moral response. ${ }^{5}$ An illustration of the way in which normative intimations arising from nature can play into conduct is provided by Holmes Rolston III. He describes how, following the fall of the famous drive-through Wawona tree in the storms of 1968-69, the rangers of Yosemite National Park refused to cut a tunnel through another sequoia on the grounds that to do so would be an indignity to a majestic sequoia, it perverted the trees (Rolston III, 1999).

In sum, participation in the innate epistemological mystery of emplaced self-arising nature opens us to truth in its most primordial form: experience of the appearing (and disappearing) of things themselves in their many facets and ontological interrelationships that display their own integrity and normative character. Here something of the fundamental character of human being is foregrounded: a non-anthropocentric receptivity to things themselves in their mystery and with their innate value. Previous argument has shown this to be an essential potentiality of human consciousness. The intimations that it provides ground humankind. Put another way, at the heart of authentic human essence is the holding sway of truth conceived as an attitude of loving allowance. This offers its most authentic possibilities of engagement. In this sense human con-

5 This is not to deny that we need to be alert to occasions where the normativity claimed to be experienced in 'nature' and what is taken to be 'natural' is recruited to authenticate some ideological position, for example, concerning hierarchical power relationships or patterns of 'right' behavior, such as those associated with gender (see, for example, Haraway, 1991). The possibility of reading norms and values into nature to suit particular prejudices is real, but should not persuade us simply to suspend or disparage, in any wholesale way, experiences of value and normative measures that genuine openness to nature can provide. The imposition of an ideological agenda is a far cry from the receptivity to otherness that the phenomenological approach - and this paper - advocate. To assume otherwise is to deny an important source of unity with nature that can inform and ground us in significant ways. I have addressed these issues more fully in Retrieving Nature. Education for a Post-Humanist Age (Bonnett, 2004, Chs. 4 \& 5). sciousness is essentially sustaining and sustained. In concluding this section, I return briefly to those motives that subvert this mutuality with nature in our late-modern time.

\section{Scientism and thinking}

In an earlier section I sketched a constellation of motives and ideas that constitute a metaphysics of mastery and that have encouraged both a disengagement from our immediate experience of nature and the rise of scientism. In rounding up this section of the paper I will briefly indicate how this stance can impact on the character of the thinking that conventionally informs environmental education.

Perhaps the first and most fundamental point to emphasize is that scientism denies, or heavily obscures, nature as the self-arising. Its implicit assumption that nature is most authentically revealed through objectification and the procedures of experimental science is widely shared. It also closes off alternative ways of revealing nature, either by complete occlusion or by making them appear inadequate to the true nature of the phenomena. Hence, often it is considered that, where possible, nature is best revealed in the laboratory where events can be carefully controlled and attention is narrowly focussed, rather than in the field where all manner of things can occur and attention be 'distracted' by what become regarded as unwanted 'variables'. Clearly, on the basis of previous argument, such displacement of things constitutes the epitome of annihilating them in their being: they are completely removed from the previously described ontological relationships that constitute their participating in a natural place-making.

This pervasive drive to enframe phenomena in accordance with narrow human purposes is nicely illustrated in the writing of John Dewey (1909). At one point, in a chapter entitled 'The analysis of a complete act of thought' he outlined an influential schema of five 'logically distinct steps' for how we think, and that for him constitute the development 
of 'mental power'. According to Dewey the process of thinking begins with a felt difficulty; we then locate and define the difficulty; we suggest a possible solution; we develop by reasoning the bearings of the suggestion; we undertake further observation or experiment that leads to the acceptance or rejection of the suggestion. These steps have been commonly expressed as the stages of puzzlement, problem definition, hypothesising, testing, and drawing conclusions, and clearly extol a scientific approach to thinking. Dewey goes on to observe that on this model 'The problem fixes the end of thought and the end controls the process of thinking' (Dewey, 1909, p. 12).

From the perspective being developed in this paper, this latter raises a serious concern. The stage of problem definition comes early in the process and therefore holds out the danger of closing off openness to the fullness of things themselves: they become perceived instrumentally, simply as so much data whose significance in thought lies solely in their relevance to the resolution of a pre-defined problem. Insofar as Dewey's schema is an accurate portrayal of scientific thinking - or, if not that, at least informs how this thinking is commonly represented in everyday culture - it reinforces concerns about such an approach becoming insinuated in thinking more widely, and the idea of it being set up as arbiter of good thinking in general, as with scientism. ${ }^{6}$

\section{Conclusion}

A central theme to emerge from this paper is that the fundamental aim of environmental education must be to promote experience of, and understanding of, what is truly environing: the character of our emplacement. In this regard, it has been argued that it is not scientific descriptions, theories and mathematical equations that primordially hold us in our world - as scientism inclines us to

6 I have amplified these, and related, concerns in Bonnett (2013). believe. Rather, it is our felt encounters with the elemental. The coming into presence of things in their native occurring, and the resonating of birth, death, growth, decay, movement and stillness, sound and silence, lightening and darkening, rightness and wrongness, happiness and grief, the presence of others and the embrace of solitude: it is through our experience of, and participation in, such phenomena that we inhere in the cosmos. Primarily, this participation involves, not rational objectification and analysis in the service of effective autonomous agency, but non-rational receptivity and the capacity to be affected by the other, such that our agency is informed by an intimate situated knowledge of things themselves. This kind of participation is articulated in works of poetry rather than works of science. Only in this open receptive-responsive mode - previously characterized as a 'loving allowance' - can we become properly aware of the truth of our environmental situation and the proper sources of reference in assessing it and responding to it. On the account developed in this paper, global warming and pollution, massive deforestation, industrial fishing methods, and so forth, are properly evaluated not exclusively in terms of their impacts on our ability to satisfy current or future anthropocentric desires, but through a sense of their fittingness in the context of the powers, rhythms, integrity, normativity and intrinsic values of the otherness of nature in which human existence is embedded.

It is in this sense that the idea of sustainability remains highly pertinent to environmental education. If, as has been argued, sustainability as a letting things $b e$ - that is, as themselves in their particularity and mystery - lies at the heart of human consciousness, it becomes a central educational consideration in two very important and related senses. First, it articulates something that is central to the enterprise of nurturing authentic human being. This, surely, must lie at the heart of a proper and full education. Second, sustainability as a receptive/ responsive frame of mind is essential for us properly to address the environmental situation that we 
now face. Only a frame of mind that has eschewed the overweening instrumentality and scientism that is now so pervasive - that is to say, has risen above the metaphysics of mastery that would have us understand everything as essentially a mutable resource - can be open to the truth of things themselves, including ourselves. Only when released towards things in nature in this way can we see what is really going on, re-establish the potential fullness of our environmental consciousness and (re-)gain a set of normative indicators that can inform our perceptions and behaviour in ways properly attuned to our current human/environmental situation.
Granted this, a central task of education becomes to find opportunities to reveal and disturb those taken for granted assumptions of the metaphysics of mastery as it continues to hold sway (often tacitly) in the life and language of educational institutions and beyond, and to create spaces for a fully embodied receptive and reflective engagement with nature. ${ }^{7}$ It will need to nurture those modalities of perception that enhance this and that are intimated by the kind of whole-hearted engagement with nature described in this paper. Harking back to my discussion of Arendt: it will need to help us to learn how to receive the gift of the given.

\section{References}

- Abram, D. (1996). The spell of the sensuous. New York: Vintage Books.

- Arendt, H. (1978). The life of the mind. San Diego: Harcourt.

- Arendt, H. (1998). The human condition (2 ${ }^{\text {nd }}$ edition). Chicago: University of Chicago Press.

- Blenkinsop, S. (2012). Four slogans for cultural change: An evolving place-based, imaginative and ecological learning experience. Journal of Moral Education. 41 (3), 353-368.

- Bonnett, M. (1995). Teaching thinking, and the sanctity of content. Journal of Philosophy of Education. 29 (3), 295-309.

- Bonnett, M. (1999). Education for sustainable development: A coherent philosophy for environmental education? Cambridge Journal of Education. 29 (3), 313-324.

- Bonnett, M. (2004). Retrieving nature: Education for a post-humanist age. Oxford: Blackwell.

- Bonnett, M. (2012). Environmental concern, moral education, and our place in nature. Journal of Moral Education Special Issue: Moral Education and Environmental Concern. 41 (3), 285-300.

- Bonnett, M. (2013). Normalising catastrophe: Sustainability and scientism. Environmental Education Research. 19 (2), 187-197.

- Bonnett, M. (2015). The powers that be: Environmental education and the transcendent. Policy Futures in Education. 13 (1), 42-56.

- Bonnett, M. (2016). Environmental consciousness, sustainability, and the character of philosophy of education. Studies in Philosophy and Education. DOI: 10.1007/s1 1217-016-9556-x.

7 See, for example, Blenkinsop (2012) for an account that relates this consideration to the character and location of schools as places of learning. See, also, Postma and Smeyers (2012) for arguments in support of the role of open-ended learning in natural environments in developing environmental responsibility. A useful examination of place-conscious education can be found in Greenwood (2013), and in Ontong and Le Grange (2014). 
- Bowers, C. (2001). Computers, culture, and the digital phase of the industrial revolution. The Trumpeter. 17 (1), 1-16.

- Brundtland Commission (1987). Our common future. Milton Keynes: Open University Press.

- Capra, F. (1982). The turning point. New York: Simon and Schuster.

- Dewey, J. (1909). How We Think. Boston: Heath.

- Glacken, C. J. (1967). Traces on a Rhodian shore. Nature and culture in western thought from ancient times to the end of the eighteenth century. Berkley: University of California Press.

- Greenwood, D. (2013). A critical theory of place-conscious education. In: Stevenson, R., Brody, M., Dillon, J. \& Wals, A. (Eds.). International handbook of research on environmental education. New York: AERA and Routledge.

- Haraway, D. (1991). Simians, cyborgs, and women. The reinvention of nature. London: Free Association Books.

- Heidegger, M. (1972). Being and time. Oxford: Blackwell.

- Heidegger, M. (1977). The question concerning technology and other essays. New York: Harper \& Row.

- Heise, U. (2008). Sense of place and sense of planet. Oxford: Oxford University Press.

- Husserl, E. (2001). Logical investigations. Volume II. London: Routledge.

- Jickling, B. (1992). Why I don't want my children to be educated for sustainable development. Journal of Environmental Education. 23 (4), 5-8.

- Joldersma, C. W. (2009). How can science help us care for nature? Hermeneutics, fragility, and responsibility for the earth. Educational Theory. 59 (4), 465-483.

- Kant, I. (1970). Critique of Pure Reason. London: Macmillan.

- Merleau-Ponty, M. (1962). The phenomenology of perception. London: Routledge \& Kegan Paul.

- Ontong, K. \& Le Grange, L. (2014). The role of place-based education in developing sustainability as a frame of mind. South African Journal of Environmental Education. 30, 27-38.

- Postma, D. W. \& Smeyers, P. (2012). Like a swallow, moving forward in circles: On the future dimension of environmental care and education. Journal of Moral Education. 41 (3), 399-412.

- Rolston III, H. (1999). Ethics on the home planet. In: Weston, A. (Ed.). An invitation to environmental philosophy. Oxford: Oxford University Press.

- Skulason, P. (2015). The wildness of nature. Its significance for our understanding of the world. In: Kemp, P. \& Frolund, S. (Eds.). Nature in education. Zurich: LIT Verlag.

- UNCED (1992). Agenda 21. New York: UNCED. 


\section{Мајкл Р. Бонет}

Универзитет у Кембриџу, Педагошки факултет, Велика Британија

\section{Одрживост, природа, образовање: феноменолошко истраживање}

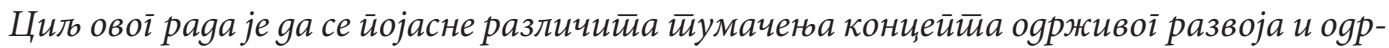

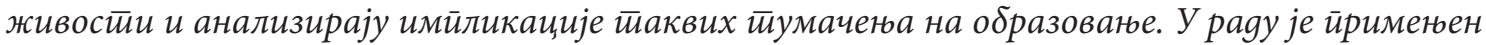

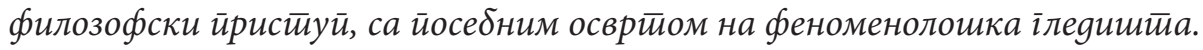

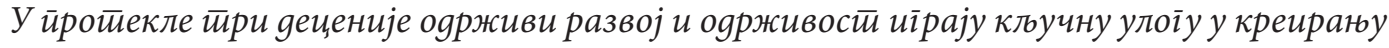

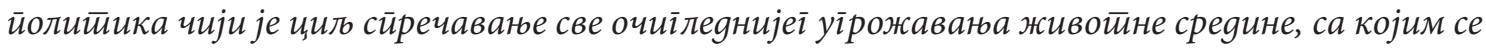
суочава савремено човечансииво. Осим иито ова два концеитиа у великој мери уйичу на усме-

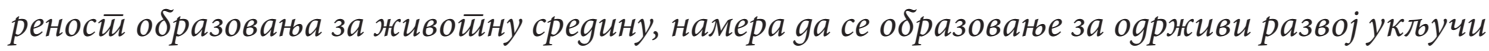
у насииавне йланове и ӣроіраме чини срж истиоријскоі докуменйа Аїенgа 21, који су gржаве

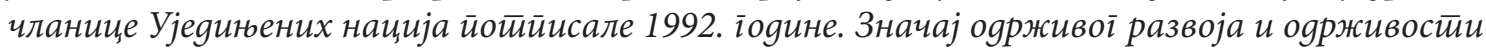

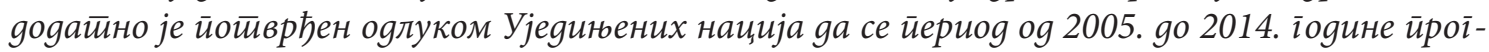
ласи Деценијом образоваға за оярживи развој.

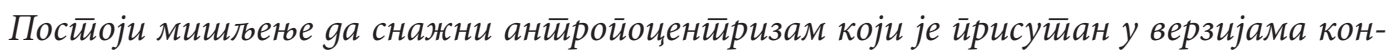

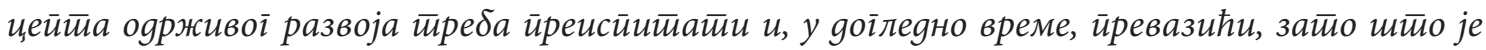
он израз яубоко укоренене „метиафизике наямоћи“, која је ілавни „кривач“ за лоше ситағе у којем се налази живойна средина. Ароїанйна йежна gа їосиоларимо ириродом не само

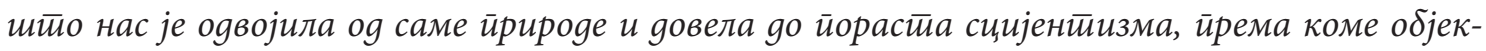

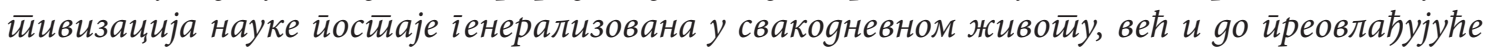

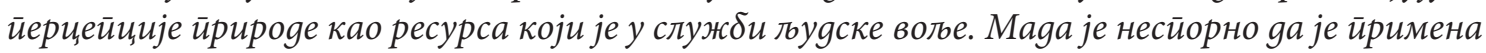

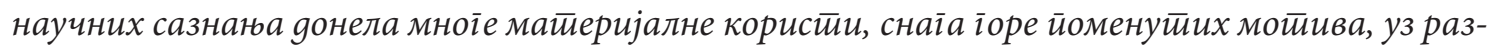

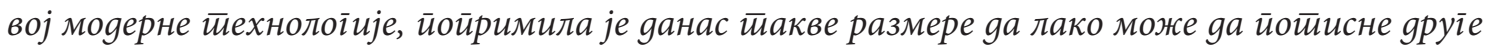
важне начине на које се односимо йрема светиу који нас окружује.

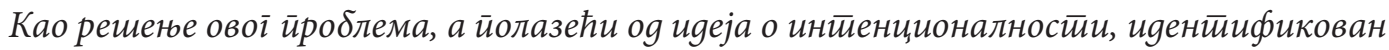

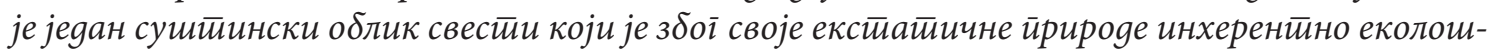

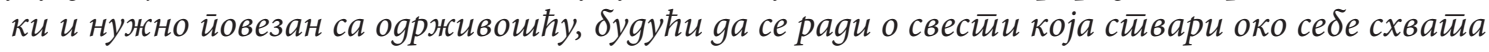

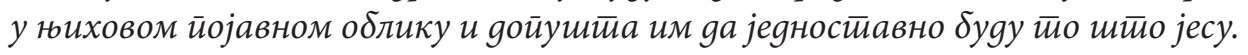

Данас се развија феноменолоіија иррирове која йрирову доживљава као инхерениино

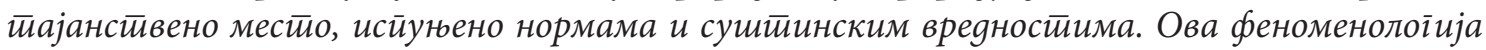

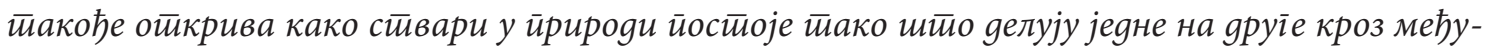

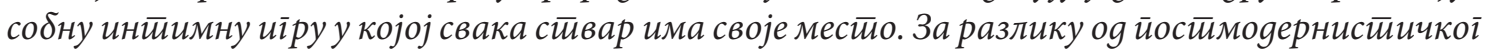

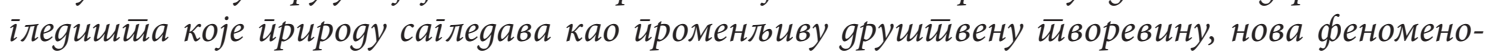

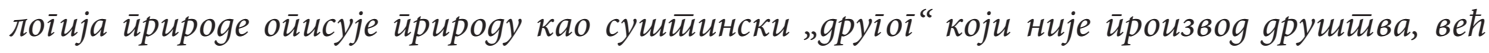

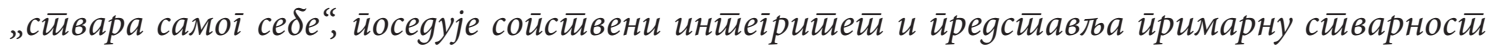
за екстиайичку свести.

Горе навеgени арі̄уменити ӣокрећу нека важна йеgаїошка йитиана. Најважније је схва-

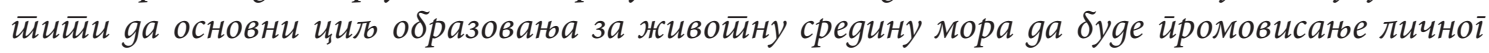
gоживљаја, а йойом и разумевана оноїа шйо нас заисииа окружује. Друіим речима, разу- 


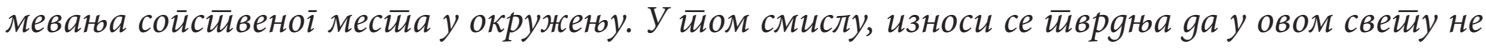
ойсйајемо йако gуі̄о захватьуући научним ойисима и йеоријама - у шйа сиијенииизам на-

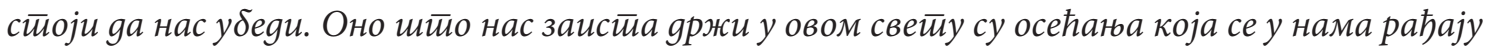

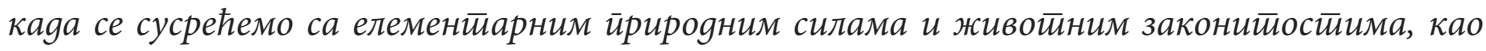

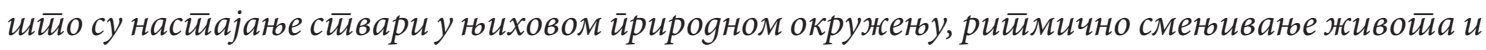

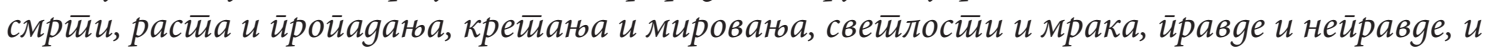
мноїих gруїих ӣојава. Да бисмо учестивовали у оваквим феноменима, не можемо се остағайи на рационалну објекиичфикаиију и анализу као средстива за усиешно ауйономно деловане,

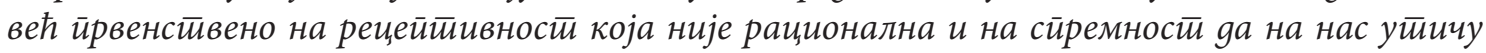

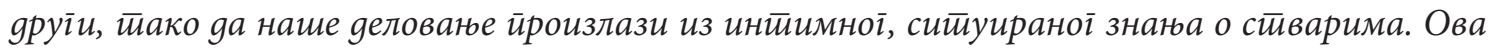

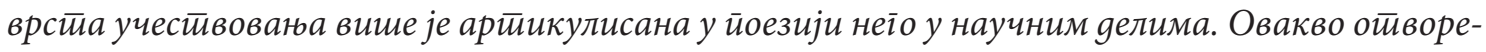

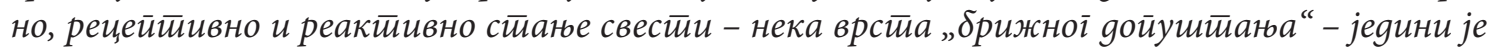
начин gа йостианемо свесни ирраве истинне о сииану у којем се налази живойна средина, као и оgі̄оварајућих извора за йрочену йої сйань и налажене решеньа.

Неки йврgе gа су ілобално заіреване и заїађене, масовна сеча иума, индустиријски

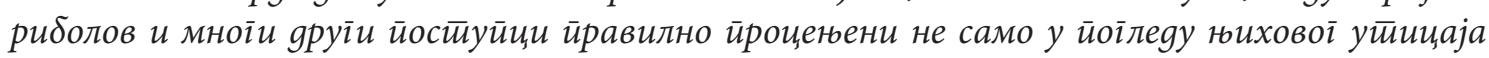

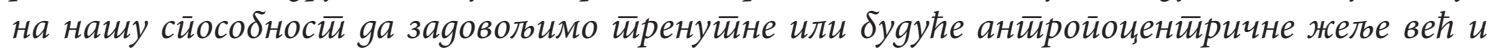

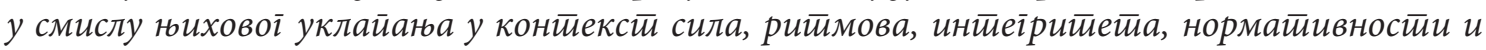

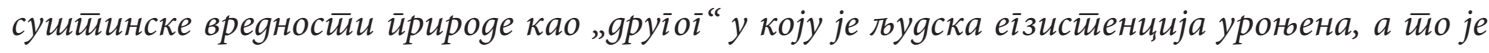

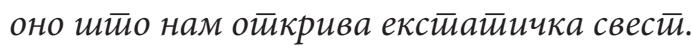

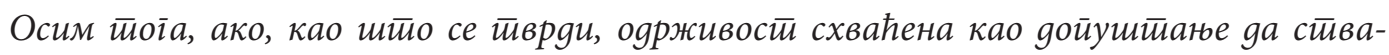

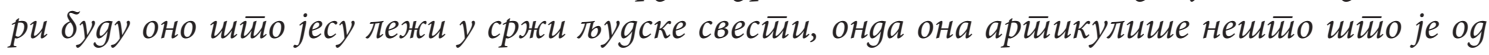

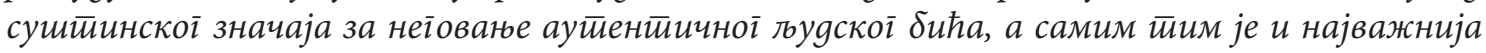

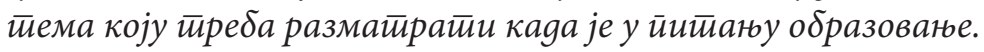

Каgа све іоре навеgено узмемо у обзир, ілавни заяайак образована је да ӣронађе начине на које ће разойкритии и из корена уздрматии начела метиабизике наямоћи која се узимају

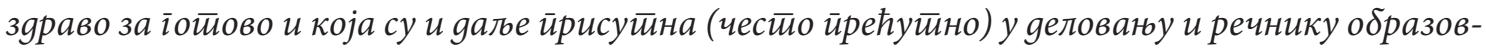

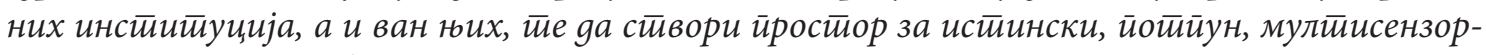
ни, рецеитиивни и рефтексивни оянос ирема йрирояи.

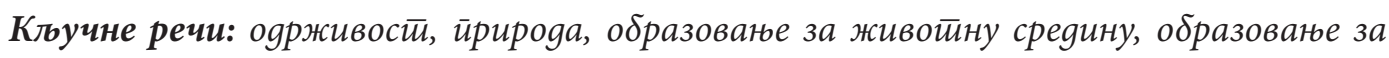
оярживи развој. 